Prof. dr. Osman Ramić ${ }^{1}$ i Nedim Botić, bachelor islamske vjeronauke

\title{
OSNOVE ISLAMSKOG POGLEDA NA KONCEPT EMOCIONALNE INTELIGENCIJE
}

\section{Sažetak}

Obradom teme Osnove islamskog pogleda na koncept emocionalne inteligencije, nastojalo se dati pojmovno određenje emocionalne inteligencije, kao relativno novijeg naučnog pojma $i$ njene povezanosti sa islamskim učenjem. Nastojao se sagledati $i$ analizirati koncept emocionalne inteligencije u svjetlu islamskog učenja $i$ njeno mjesto $u$ izvorima islama. Islam, kao univerzalni koncept života, nudi rješenja za sva pitanja i probleme čovječanstva, sve do Sudnjeg dana, $i$ u njemu nalazimo integrirane elemente emocionalne inteligencije.

Emocionalna inteligencija, kao bitna odrednica uspješnog rada i funkcioniranja, uključuje: emocionalnu osjetljivost, interpersonalne $i$ intrapersonalne sposobnosti, socijalnu osjetljivost, komunikativnost, visok nivo tolerancije, visok nivo adaptabilnosti, socijabilnost, kooperativnost $i$ svakodnevnu saradnju u različitim životnim situacijama i okolnostima.

Harmonični međuljudski odnosi u svim strukturama, osnovni su preduvjet uspješnog rada $i$ življenja, a za to je potrebna visoka emocionalna inteligencija. Zato joj s pravom D. Goleman daje prednost u odnosu na akademsku inteligenciju.

Razvijena emocionalna inetligencija je potrebna odgajateljima, zdravstvenim radnicima, menadžerima, političarima, pedagozima, psiholozima, socijalnim radnicima, terapeutima, advokatima, sudijama, policajcima i svima drugima.

I dalje ostaje potreba dubljeg $i$ sveobuhvatnijeg istraživanja $i$ proučavanja uloge $i$ značaja emocionalne inteligencije u savremenom životu i radu.

Ključne riječi: islam, emocije, emocionalna inteligencija, interpersonalna $i$ intrapersonalna osjetljivost, empatija

\footnotetext{
${ }^{1}$ Pedagoški fakultet Univerziteta u Bihaću i Islamski pedagoški fakultet u Bihaću
} 


\section{UVOD}

Najveća hvala i zahvala pripada samo Uzvišenom Allahu, neka je salavat i selam na najodabranijeg Allahovog roba Muhammeda, sallallahu alejhi ve sellem, na njegovu časnu porodicu, njegove ashabe i sve one koji ga u dobru slijede do Sudnjeg dana.

Koncept emocionalne inteligencije i njena povezanost $\mathrm{s}$ univerzalnim islamskim učenjem prestavlja relativno novo područje naučno-istraživačkog rada. Glavni elementi svoje mjesto nalaze unutar postulata islama objavljenih prije 1400 godina. Islam, kao univerzalni koncept života, nudi rješenja za sva pitanja i probleme čovječanstva, sve do Sudnjega dana i svoje sljedbenike podučava i odgaja na najljepši i najplemenitiji način, te predstavlja idealan program življenja objavljen od Uzvišenog Allaha radi dobrobiti čitavog čovječanstva.

$\mathrm{Na}$ početku teme obrađuju se osnovne teorijske komponente emocionalne inteligencije, pojam emocija, njihova osnovna podjela, te opći pogled na pojam emocionalne inteligencije.

Emocionalna inteligencija je sposobnost prepoznavanja osjećaja, njihova jasnog identificiranja, razumijevanja, sposobnost njihova kontroliranja i korištenja za izražavanje misli. Za osobe $\mathrm{s}$ visokim kvocijentom emotivne inteligencije je karakteristično da uspješno prepoznaju vlastite i tuđe emocije, potrebe i želje, te imaju razvijene vještine samokontrole i rada s drugima osobama.

Islamsko učenje podstiče na usvajanje pozitivnih vještina emocionalne inteligencije u oblastima morala, međuljudskih odnosa i odnosa čovjeka i drugih živih bića. Navodi se, također, kako islam gleda na negativne emocionalne reakcije, uz navođenje primjera iz Kur'ana i sunneta.

O navedenoj temi je na bosanskom jeziku dostupna oskudna literatura, te je svega objavljeno jedno djelo koje se direktno dotiče problematike rada. To je rad dr. Me'muna Mubejjida pod naslovom: Nauči vladati svojim emocijama - emocionalna inteligencija; naučni i islamski pogled, koja je objavljena u Sarajevu 2008. godine. Dakle, postoji mnogo prostora za daljnji rad na izučavanju emocionalne inteligencije, kao značajne dimenzije ličnosti, koja obezbjeđuje uspješno djelovanje $\mathrm{i}$ funkcioniranje $u$ savremenom 
konceptu ljudskog života. Brojne su profesije koje, za uspješan rad, neminovno zahtijevaju posjedovanje emocionalne inteligencije. Poslovi u oblasti odgoja i obrazovanja, zdravstvene zaštite, socijalne skrbi i kao i rad u drugim institucijama, ustanovama i organizacijama koje se neposredno ili posredno bave pitanjima pomoći i zaštite čovjeka, traže visoke kompetencije koje uključuju sposobnost razumijevanja drugih, dakle, visok nivo emocionalne inteligencije.

\section{DEFINICIJA I POJAM EMOCIJA}

U pojmovnom određenju koncepta emocionalne inteligencije susrećemo se s pojmom emocija kojeg ćemo nastojati ukratko objasniti u daljnjem dijelu rada. Naime, ljudi nisu isključivo racionalna bića koja svoje postupke i htijenja preduzimaju samo na osnovu umnog mišljenja i zaključivanja. Mnogi naši postupci bivaju izazvani i drugim činiocima, kao što su npr. emocije (osjećanja). Emocije se, stoga, mogu opisati kao doživljaj našeg vrednovanja i subjektivnog odnosa prema stvarima, ljudima, događajima i prema sopstvenim postupcima.

Salovey i Mayer definišu emocije kao: „Emocije su organizovani odgovori koji prelaze granice mnogih psiholoških podsistema, uključujući fiziološki, kognitivni, motivacioni i iskustveni podsistem. Najčešće se javljaju kao odgovor na događaj, bilo spoljašnji ili unutrašnji, koji ima pozitivno značenje za osobu. “2

Postoji, ne samo u našem jeziku, već i u mnogim drugim jezicima veliki broj izraza koji izražavaju različita emocionalna stanja, a to su: radost, žalost, ljubav, saučešće, empatija, ponos, zluradost, oholost, stid, zahvalnost, briga, strepnja, očekivanje, nada itd. Emocije su u toku svog razvoja propraćene brojnim spoljašnjim i unutrašnjim promjenama. Značajni spoljašnji znaci emocija su: izrazi lica, tjelesna napetost, glasovne reakcije, znojenje, bljedilo, rumenilo i sl. Također, postoje i unutrašnji pratioci kao karakteristične promjene u radu

${ }^{2}$ Izvorni tekst definicije: "We view emotions as organised responses, crossing the boundaries of many psychological subsystems, including the psysiological, cognitive, motivational, and experiental systems. Emotions typically arrise in response to an event, either internal or external, that has a positively or negatively valenced meaning for the individual." Preuzeto iz: Peter Salovey and John D. Mayer (1990). Emotional intelligence. Baywood Publishing. Str. 186. 
pojedinih organa: ubrzan rad srca, ubrzano disanje, stomačne tegobe $\mathrm{i}$ sl. Svaka emocija uključuje:

1. FIZIOLOŠKI DIO (promjene u organizmu koje doživljavamo kao uzbuđenje, tahikardiju, brže i dublje disanje);

2. INTELEKTUALNU KOMPONENTU (saznanje o promjenama u organizmu);

3. MIKRO I MAKROMIMIKA (facijalna ekspresija, pokreti, položaj tijela, ponašanje).

\section{POJAM INTELIGENCIJE}

Inteligencija je mentalna karakteristika koja se sastoji od sposobnosti za učenje iz iskustva, prilagodbe na nove situacije, razumijevanja i korištenja apstraktnih pojmova, korištenja znanja za snalaženje u novoj okolini u kojima ne pomaže stereotipno nagonsko ponašanje, a niti učenjem stečene navike, vještine i znanja. ${ }^{3}$ Riječ inteligencija potiče od latinske riječi inteligere i znači razumjeti, shvatiti. Psiholozi koriste inteligenciju kao crtu ličnosti ${ }^{4}$ koja može barem djelomično protumačiti način na koji ljudi reaguju ili se ponašaju u različitim situacijama. Prema jednom mišljenju, inteligencija je sposobnost rješavanja novih problema i snalaženja $u$ novonastalim situacijama; prema Davidu Wechsleru ${ }^{5}$, inteligencija je „sposobnost razumijevanja svijeta i domišljatost $\mathrm{u}$ sučeljavanju $\mathrm{s}$ njegovim izazovima“. ${ }^{6}$ Drugi, pak, smatraju da inteligencija obuhvata sposobnost apstraktnog razmišljanja, razumijevanje uzroka i posljedica nekog problema, sposobnost razlikovanja bitnog od nebitnog, sposobnost učenja i prilagođavanja nekom zadatom cilju. Poneki autori se skoncentrišu na sposobnost lahkog i brzog učenja i

\footnotetext{
${ }^{3}$ http://hr.wikipedia.org/wiki/Inteligencija

${ }^{4}$ Crta ličnosti predstavlja razlikovnu karakteristiku za koju se pretpostavlja da tumači dosljednost u ponašanju. Preuzeto iz: Rathus, S. A. (2000.). Temelji psihologije. Jastrebarsko: Naklada Slap. Str. 144.

${ }^{5}$ David Wechsler (1896 - 1981.) je bio vodeći američki psiholog. Razvio je poznate skale inteligencije, kao što su Wechslerova skala inteligencije za odrasle osobe (WAIS) i Wechslerova skala inteligencije za djecu (WISC). Pogledati: http://en.wikipedia.org/wiki/David_Wechsler

${ }^{6}$ Rathus, S. A. (2000.). Temelji psihologije. Jastrebarsko: Naklada Slap. Str. 143.
} 
sposobnost sticanja novih sposobnosti. Psiholozi su grupisali inteligenciju u tri glavne grupe:

- apstraktna inteligencija (sposobnost razumijevanja i upravljanja korištenjem verbalnih i matematičkih simbola);

- konkretna inteligencija (sposobnost razumijevanja i upravljanja objektima);

- socijalna inteligencija (sposobnost razumijevanja ljudi i povezivanja s njima).

\subsection{Koncept emocionalne inteligencije}

Emocionalna inteligencija (EI) ima korijene $\mathrm{u}$ konceptu "socijalne inteligencije"7, koju je po prvi put identifikovao E.L. Thorndike $^{8}$, 1920. godine. Uticaj ovog koncepta na širu kulturnu i akademsku zajednicu je od tada bio brz i širok. Utemeljenje za pojavu koncepta emocionalne inteligencije pronalazimo $\mathrm{u}$ Gardnerovoj (1983.) teoriji višestrukih inteligencija, tačnije u podjeli socijalne inteligencije na interpersonalnu i intrapersonalnu; i Sternbergovoj (1985.) triarhičkoj (trosložnoj) teoriji inteligencije (praktična inteligencija).

Interpersonalnu inteligenciju Gardner ${ }^{9}$ definiše kao: "...znanje o unutrašnjim aspektima osobe: pristup svojim osjećanjima, rasponu

${ }^{7}$ Socijalna inteligencija je poseban vid inteligencije, koji obuhvata više međusobno
povezanih sposobnosti kao što su: emocionalna osjetljivost, socijalna analitičnost,
dobra samokontrola, socijabilnost, tolerancija i socijalna adaptabilnost. Socijalna
inteligencija obuhvata i sposobnost tačnog prepoznavanja i razumijevanja osjećanja
drugih, kao i pronicljivost u otkrivanju i tumačenju često skrivenih namjera drugih,
interpersonalnih stavova na osnovu primjetnih znakova u ponašanju. Neophodna je
za uspješan rad menadžera, političara, psihologa, socijalnih radnika, terapeuta,
advokata, policajaca i drugih koji su upućeni na rešavanje problema pojedinaca i
grupa ljudi. Izvor: http://sr.wikipedia.org/sr-el/ ${ }^{8}$ Edward Lee Thorndike (1874 - 1949.) je bio američki psiholog koji je gotovo čitav radni vijek proveo na Univerzitetu Columbia. Njegovo istraživanje ponašanja životinja i procesa učenja je dovelo do pojave teorije konekcionizma i postavilo znanstvene temelje modernoj pedagoškoj psihologiji. Izvor: www.wikipedia.com

9 Howard Gardner (Skrenton, Pensilvanija, SAD, 11. juli 1943) je američki psiholog najpoznatiji po svojoj teoriji višestruke inteligencije. Gardner je istraživao koncepte kreativnosti i inteligencije i udio koji zauzimaju u učenju djece. Pisao je knjige o kognitivnoj revoluciji (Nova vještina uma) i nekoliko tomova o velikim 
emocija, mogućnost razlikovanja tih osjećanja i, eventualno, imenovanja osjećanja i u njima traženje značenja i razumijevanja uzroka sopstvenog ponašanja". ${ }^{10}$ Sternberg $^{11}$ gleda na inteligenciju pod vidom obrade ili procesiranja informacija. Motivisan rezultatima svojih istraživanja, on zaključuje da snalaženje u svakodnevnim situacijama zahtijeva drugačije sposobnosti od onih koje mjere klasični testovi inteligencije. Sternberg tako, uz analitičku i kreativnu, u svoju teoriju uvrštava i praktičnu inteligenciju. ${ }^{12}$

Gardner (1993.) je u svoj model višestrukih inteligencija, među sedam $^{13}$ osnovnih, uvrstio i dva oblika ličnih inteligencija: interpersonalnu, koja označava sposobnost prikladnog reagovanja $u$ odnosima s drugim ljudima i intrapersonalnu koja označava suštinu samospoznaje i sposobnosti upravljanja osjećanjima. Triarhička teorija i teorija višestrukih inteligencija su, uprkos povremenim otporima, prošle mnoge provjere i svrstane su ravnopravno s ostalim već prihvaćenim teorijama inteligencije (Spearmanovom, Thurstoneovom, Guilfordovom).

Pojam ,emocionalna inteligencija“ prvi put se u akademskom kontekstu pojavio 1985. godine, u naslovu doktorske disertacije W. L. Paynea. Međutim, čak nekoliko godina nakon toga niko se nije osvrnuo na navedeni izraz. Smatra se da su naučnici Peter Salovey sa Univerziteta u Yaleu i John D. Mayer sa Univerziteta New Hempshire prvi pokušali da preciznije definišu navedeni pojam. Oni su u skladu sa naučnom metodologijom razvijali modele i instrumente za procjenu

vođama i misliocima 20. vijeka (Izvanredni umovi, Kreativni umovi, Vodeći umovi). Izvor: http://sr.wikipedia.org/

${ }^{10} \mathrm{http}: / /$ gencelowich.blogspot.com/2008/10/1.html

11 Robert Sternberg (engl. Robert Jeffrey Sternberg, 8. decembar 1949.) je američki psiholog i psihometričar, bivši predsjednik Američkog psihološkog društva, profesor psihologije na Univerzitetu Jejl. Istraživao je ljudsku inteligenciju, vrste mišljenja, kogniciju, ljubav i mržnju i informativno procesne procedure koje koriste ljudi pri rješavanju zadataka $\mathrm{u}$ testovima inteligencije. Izvor: http://sr.wikipedia.org/sr

12 Rathus, S.A. (2000). Temelji psihologije. Str. 347.

${ }^{13}$ Gardner smatra da ne postoji samo jedna, već sedam inteligencija, čiju osnovicu čine različita područja mozga. U njih se ubrajaju: jezična sposobnost, logičnost, tjelesna nadarenost, muzička sposobnost, spacijalne vještine i dvije vrste personalne inteligencije: intrapersonalna $\mathrm{i}$ interpersonalna osjetljivost. Pogledati: Rathus, S.A. (2000.). Temelji psihologije. Str. 346. 
EI. Salovey i Mayer definišu emocionalnu inteligenciju kao: „Vrsta socijalne inteligencije povezana sa sposobnošću ličnosti da kontrolira vlastite emocije $i$ osjećaje $i$ emocije drugih, a povezana je $i$ sa sposobnošću ličnosti da uviđa razliku između njih i mogućnošću korištenja ovih informacija u usmjeravanju vlastitih misli $i$ osjećaja. " 14

Esther Orioli i Robert Cooper su izjavili slijedeće u pokušaju da objasne EI: „EI je mnogo više od „lijepog” ponašanja prema drugima. To je sposobnost da osjetimo, razumijemo $i$ uspješno primijenimo moć $i$ mogućnost emocija kao izvora energije, informacija, kereativnosti, povjerenja i bliskosti”. Ukratko definirana, emocionalna inteligencija je sposobnost da se opaze emocije, da im se priđe i da se izazovu, kako bi pomogle procesu mišljenja. Svoju popularnost koncept emocionalne inteligencije bilježi pojavom knjige psihologa Danijela Golemana ${ }^{15}$. On je pojam emocionalne inteligencije suprotstavio pojmu akademske inteligencije, naglasivši superiornost emocionalne inteligencije u prognozi različitih oblika uspješnosti u svakodnevnom životu pojedinca. Golemanova knjiga "Emocionalna inteligencija - zašto je važnija od kvocijenta inteligencije” je dvije godine bila bestseler u SAD.

\subsubsection{Dimenzije emocionalne inteligencije}

Emocionalna inteligencija je usko povezana $s$ psihološkim osobinama koje se nalaze u karakteru pojedinca, odnosno ovisi o psihološkim faktorima, kao što su ekstrovertiranost/introvertiranost ${ }^{16}$

\footnotetext{
${ }^{14}$ Izvorni tekst definicije: "We define emotional intelligence as the subset of social intelligence that involves the ability to monitor one's own and other's feelings and emotions, to discriminate among them and to use this information to guide one's thinking and actions". Preuzeto iz: Peter Salovey and John D. Mayer. Emotional intelligence. Str. 189.

${ }^{15}$ Danijel Goleman (rođen 7. marta, 1946) je književnik, psiholog i znanstveni publicista. Radio je 12 godina za novine The New York Times, specijalizirajući se za psihologiju i neurologiju. Pisac brojnih djela, od kojih je, svakako, najpoznatija knjiga: Emocionalna inteligencija - zbog čega je važnija od kvocijenta inteligencije. Izvor: http://en.wikipedia.org/wiki/Daniel_Goleman

${ }^{16}$ Ekstraverzija je prema K. G. Jungu, stav okrenütosti libida ka objektu, ka spoljašnjem svijetu. Za ekstraverziju je karakteristično da ličnost veću pažnju pridaje događajima u spoljašnjoj, nego zbivanjima u unutrašnjoj, psihičkoj realnosti. Aktivna ekstraverzija označava namjerno usmjeravanje pažnje na spoljašnju
} 
ili emotivnost/indiferentnost. Razina naše emocionalne inteligencije nije određena genetski niti se razvija u našem ranom djetinjstvu. Za razliku od kvocijenta inteligencije, koji se neznatno mijenja nakon desete godine života, emocionalna inteligencija je uvelike naučena $\mathrm{i}$ nastavlja se razvijati kako živimo i učimo iz iskustava - ta se naša vještina može i dalje usavršavati.

Zapravo, istraživanja koja su godinama pratila razinu emocionalne inteligencije pokazuju da ljudi postaju sve bolji u tim umijećima što vještije nadziru vlastite emocije i porive, što su bolji u samomotiviranju, empatiji i društvenim sposobnostima. Psiholozi Daniel Goleman i John Salovey u svojoj temeljnoj definiciji emocionalne inteligencije preuzimaju temelje Gardnerove osobne inteligencije, proširujući sposobnosti na pet glavnih područja, ili pet dimenzija emocionalne inteligencije ${ }^{17}$ :

1. Spoznaja vlastitih emocija. Svijest o vlastitome biću prepoznavanje osjećaja $u$ trenutku kada do njega dolazi - ključ je emocionalne inteligencije, te je presudna za psihološke spoznaje i razumijevanje vlastite ličnosti. Nemogućnost primjećivanja vlastitih osjećaja ostavlja nas njima na milost i nemilost. Osobe koje pouzdanije poznaju svoje osjećaje, bolje upravljaju vlastitim životom i bolje znaju što osjećaju o određenim osobnim odlukama, od toga $\mathrm{s}$ kime stupiti u brak, do toga koji posao odabrati.

2. Upravljanje emocijama. Upravljati emocijama, tako da odgovaraju situaciji, sposobnost je koja se izgrađuje na temelju svijesti o vlastitoj ličnosti, te omogućuje čovjeku da tješi samoga sebe, da se oslobodi neobuzdane tjeskobe, potištenosti ili razdraženosti - i posljedica koje sa sobom donosi neuspjeh $u$ toj temeljnoj emocionalnoj vještini. Osobe kojima ta vještina ne ide od ruke, neprestano se bore protiv osjećaja uznemirenosti i patnje, dok se oni koji su u tome dobri puno brže mogu oporaviti od životnih neuspjeha i nedaća.

realnost. Introverzija je prema Jungu, orijentacija libida ka sopstvenom, unutrašnjem, subjektivnom svijetu. Takva orijentacija podrazumijeva okretanje od spoljašnjeg svijeta $i$ od interpersonalnih odnosa ka sebi. Izvor: http://sr.wikipedia.org/sr

${ }^{17}$ Goleman, D. (2004). Emocionalna inteligencija - zašto je bitnija od kvocijenta inteligencije. Zagreb: Mozaik knjiga, Zagreb. Str. 19. 
3. Samomotivacija. Upravljanje emocijama u službi određenog cilja temeljna je sposobnost potrebna za iskazivanje usredotočene pozornosti, za samomotivacije i ovladavanje vlastitim postupcima te za kreativnost. Emocionalna samokontrola - sposobnost odgađanja primanja nagrade i zatomljavanja impulsa - temeljni je dio svakovrsnih uspjeha. A sposobnost prebacivanja u stanje plime omogućuje postizanje iznimnih rezultata svih vrsta. Ljudi koje krasi ova sposobnost, nerijetko su produktivniji i učinkovitiji, čega god se prihvatili.

4. Prepoznavanje emocija u drugima. Empatija ${ }^{18}$, još jedna od sposobnosti koja se temelji na emocionalnoj svijesti o vlastitoj ličnosti, osnovna je „vještina za ophođenje s ljudima“. Osobe koje iskazuju empatiju bolje su prilagođene suptilnim društvenim signalima koji pokazuju što je drugima potrebno ili što drugi žele. Zbog toga su takve osobe uspješnije u zvanjima poput njegovanja djece i bolesnika, u nastavi, trgovini i na rukovodećim funkcijama.

5. Snalaženje u vezama. Umijeće održavanja veze u velikoj je mjeri vještina upravljanja emocijama u drugima. Riječ je o sposobnostima koje su temelj popularnosti, karakteristika vođe i interpersonalne učinkovitosti. Osobe koje se ističu u tim vještinama postižu dobre rezultate u svemu što se oslanja na nesmetanu interakciju s drugima; to su društvene zvijezde.

\section{EMOCIONALNA INTELIGENCIJA U SVJETLU ISLAMSKOG UČENJA}

Muslimani vjeruju da je Allah stvorio svemir, i dao mu zakone iznenađujuće preciznosti. Među Svojim prelijepim stvorenjima, On je također stvorio ljude i dao im mnoge osobine: emocionalne, duhovne, intelektualne i fizičke, budući da im je On povjerio održavanje $\mathrm{i}$ zaštitu života na ovom planetu. Dakle, kako bi ljudima olakšao sprovođenje njihove misije, Stvoritelj je slao poslanike da bi ih podučili kako da žive svoj život u skladu s Njegovim zakonima.

\footnotetext{
${ }^{18} \mathrm{U}$ psihologiji, termin empatija se upotrebljava da označi proces neposrednog uživljavanja u emocionalna stanja, mišljenje i ponašanje drugih ljudi. Empatija predstavlja neposredno saznanje osjećanja, želja i namjera drugih ljudi. Izvor: http://sr.wikipedia.org/sr
} 
Islam nije samo vjera obredoslovlja, namaza, posta, zekata i drugih obreda - islam je zapravo sistem života za čovjekov praktični život u svim njegovim aspektima. Ovaj sistem podrazumijeva praktičnu organizaciju ljudskog života koja uključuje etičku osnovu na kojoj počiva društveni poredak, političko i ekonomsko uređenje.

Taj islamski sistem je sveobuhvatan, uzajamno povezan, i pokriva sve vidove ljudskog života $\mathrm{i}$ različite čovjekove potrebe $\mathrm{i}$ aktivnosti. Islam nije ograničen samo na to da bude vodič na putu do Dženneta, nego je on i način ostvarenja ovosvjetskog blagostanja. Islamski sistem života nije privremeni sistem koji pripada samo jednom historijskom razdoblju, niti je to lokalni sistem ustanovljen samo za jednu generaciju i sredinu. On je, ustvari, temeljni sistem određen od strane Uzvišenog Boga za dinamični ljudski život.

\subsection{Islam i emocionalne osobine menadžmenta}

Emocionalna interakcija je neizbježna u našim svakodnevnim životima; u stalnom smo kontaktu sa našim emocijama. Ali, do koje mjere trebamo sebi dozvoliti da utičemo na emocije drugih ili pak da druge osobe ili događaji utiču na naše emocionalno stanje?

Islam podjednaku važnost pridaje različitim komponentama ljudskog bića i regulira ih na najpotpuniji način. Islam je srednji put između dviju krajnosti: s jedne strane, nekontrolisanog prepuštanja prohtjevima i, s druge strane, sputavanja čovjekove prirode u kojoj je stvoren. Emocije u okviru islamskog učenja imaju svoje vrijednosno značenje kao fundamentalni elementi ljudske duše. Islam podučava umjerenosti u svim sferama života, nastojeći da kreira harmoniju, tako da pojedinac bude $u$ konstantnom miru sa samim sobom, univerzumom i svojim Stvoriteljem. Islam preporučuje da se izbjegavaju ekstremi u pozitivnim i negativnim emocijama, budući da su svi ekstremi pogubni, ukoliko izađu van okvira kontrole. Emocionalna inteligencija se najviše očituje $u$ islamskom moralu (ahlaku) i načinu ophođenja. Moral je složeno područje ljudskog djelovanja, čiji je predmet interesovanja odnos čovjeka prema sebi, drugim ljudima, životinjama i prirodi. Moralan odnos prema sebi, drugima, pa i široj živoj i neživoj okolini je, po islamskom učenju, ibadet. Abdullah ibn Amr ibn el-As, r.a., kaže: „Allahov Poslanik, s.a.v.s., nije bio vulgaran niti bestidan. Govorio je: 'Najbolji od vas su 
oni čije je ponašanje najljepše."'19 Islam ne potencira mnogo hereditarnu ${ }^{20}$ inteligenciju, već je njegov fokus na vještinama emocionalne inteligencije, za koje su moderni istraživači utvrdili da su one istinska mjera uspjeha u svakodnevnom životu.

\subsection{Kur'an kao preteča modernim shvatanjima o EI}

Kur'an kao Allahova posljednja Objava, sadrži mnoštvo riječi i izraza emocionalnog značenja. Njihov spomen ukazuje na bitnost emocija unutar pojedinca kao jedinke, kao i društva u cjelini. Doista, ljudski život je obojen raznovrsnim emocijama koje utiču na njegov unutarnji bitak, kao i vanjsku manifestaciju u formi djela i radnji. Ukratko ćemo pokušati navesti osnovne oblasti psihičkog i emocionalnog zdravlja, uz navođenje kur'anskih ajeta koji ih dodatno pojašnjavaju.

\subsubsection{Spoznaja suštine naših vlastitih osjećanja}

Samosvjesnost je jedno od najvažnijih područja na koje se odnosi emocionalna inteligencija. Poznavanje sebe uključuje svijest o vlastitim emocionalnim stanjima. Bez svijesti o vlastitim emocijama, upravljanje njima je nemoguće. Sve dok čovjek ne spozna prirodu svojih emocija, on ih nije sposoban razumjeti, niti shvatiti ono što drugi osjećaju. Što više poznaje svoja emocionalna stanja, osoba će biti u povoljnijoj poziciji da izabere način na koji će reagirati u pojedinim situacijama. Preduvjet koji dovodi do osvještavanja emocija u čovjeku, je mogućnost razlikovanja između onog što čovjek osjeća i onog što misli. Nakon što osoba postane svjesna svojih emocija, trebala bi provoditi samokontrolu svojih emocionalnih stanja.

Emocionalna inteligencija se temelji na prepoznavanju osjećaja $\mathrm{u}$ trenutku kad je do njih došlo. U neprekidnu pažnju unutarnjih emocionalnih procesa, uključuje se i um, koji dok preispituje iskustvo, $\mathrm{u}$ to preispitivanje uključuje i preispitivanje emocija. Kur'an, kao Allahova posljednja objava čovječanstvu, savjetuje i podstiče

${ }^{19}$ Bilježe Buharija i Muslim. Preuzeto iz: Hakki, A. M.(2004). Moral muslimana. Sarajevo:Bookline. Str. 11.

${ }^{20}$ Hereditarnost predstavlja prijenos genetičkih obilježja s roditelja na djecu. Izvor: http://www.centar-zdravlja.net/rjecnik/507/hereditarnost/ 
muslimane da proniknu u bit svojih emocija, da ih nastoje protumačiti i prihvatiti. Svijest o samome sebi osnova je samopouzdanja, i jedna od pet temeljnih odrednica emocionalne inteligencije. U islamskom učenju je ona duboko integrirana, te na nju ukazuju brojni ajeti Časnog Kur'ana. Uzvišeni Allah kaže:

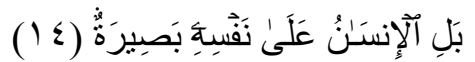

„Sam čovjek će protiv sebe svjedočiti.“21

\subsubsection{Posjedovanje istinskih emocija kao put ka empatiji}

Emocionalna inteligencija je okretanje ka našim osjećanjma i ka osjećanjima onih oko nas. Ona zahtijeva pravilan, pažljiv i samilostan odgovor na tuđa osjećanja. Empatija znači biti u mogućnosti da sagledamo problem iz perspektive druge osobe. Kur'an upućuje poziv na pokušaj shvatanja emocija drugih, i razvoj saosjećanja s njihovim stanjem. Uzvišeni Allah kaže:

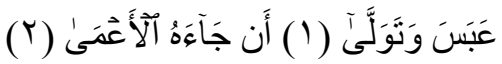

,On se namrštio i okrenuo zato što je slijepac njemu prišao. ${ }^{622}$

\subsubsection{Prilagođavanje sopstvenim emocijama}

Korijen emocionalne inteligencije je mogućnost upravljanja uznemirujućim emocijama ili impulsima. Doista, musliman se podstiče da razumije svoje emocije, da ih u svakodnevnom životu prihvati, te razgraniči između pozitivnih emocija i onih negativnih destruktivnih. Uzvišeni Allah, u Kur'anu na više mjesta spominje emocije, te nam ukazuje na kontrolu negativnih emocija. Uzvišeni Allah kaže:

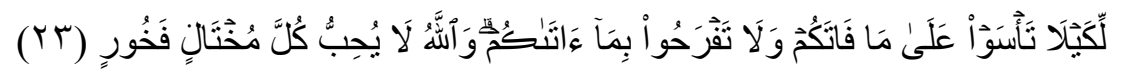

„Da ne biste tugovali za onim što vam je promaklo, a i da se ne biste previše radovali onome što vam On dade. Allah ne voli nikakve razmetljivce, hvalisavce. ${ }^{623}$

\footnotetext{
${ }^{21}$ Kur'an, El-Kijameh, 14.

${ }^{22}$ Kur'an, Abese, 1.

${ }^{23}$ Kur'an, El-Hadid, 23.
} 


\subsubsection{Popravak bolesnih emocija i podnošenje odgovornosti}

Samokontrola osjećaja postavlja čovjeka u poziciju, u kojoj je on taj koji odlučuje kako će reagirati na određenu situaciju. Tada, impulzivnost kao takva gubi na svojoj snazi, te čovjek kontrolira svoje emocije, a ne one njega. Odgovorno ponašanje, kao jedna od temeljnih vrlina emocionalne inteligencije, duboko je ukorijenjeno $\mathrm{u}$ islamskom učenju, te kao takvo rezultira korisnim ishodima i prosperitetom. Nasuprot toga, neodgovornost se povezuje sa negativnim posljedicama i sankcijama. Kur'an naglašava ličnu odgovornost i njen značaj:

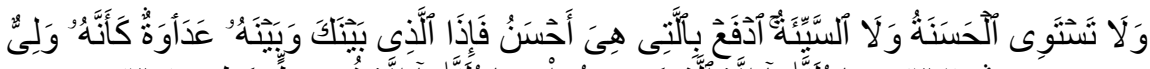

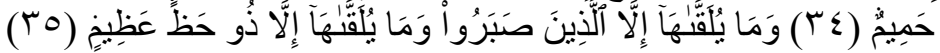

„Dobro i zlo nisu isto! Zlo dobrim uzvratite, pa će ti dušmanin tvoj odjednom prisni prijatelj postati. To mogu postići samo strpljivi, to mogu postići samo vrlo srećni.“"24

\subsubsection{Emocionalna pismenost}

Razvijena emocionalna inteligencija stavlja čovjeka u kategoriju emocionalno zrele osobe. Emocionalno zrele osobe mogu realno procijeniti situaciju $i$ na nju odgovoriti $s$ isto tako realnim $i$ prihvatljivim emocijama. Takve osobe posjeduju slobodu $u$ emocionalnom izražavanju, te $\mathrm{u}$ skladu $\mathrm{s}$ tim reaguju prema sebi i prema drugima. One znaju strukturu svojih emocija, te su stoga svjesne da ih niko, osim njih samih, ne može usrećiti. Svjesni su da svi osjećaji koje imaju, proizlaze iz njih samih, pa su zbog toga nesebični $\mathrm{u}$ interakciji s drugim ljudima. Takva emocionalna situacija daje im neograničenost $u$ vlastitom djelovanju koju, upravo zbog toga što je i sami imaju, mogu dati i drugima. Također, emocionalno zreli ljudi kreću se na vrlo kvalitetan način kroz međuljudske odnose. Kur'an poziva muslimane da izraze osjećanja koja se u njima nalaze. Uzvišeni Allah kaže:

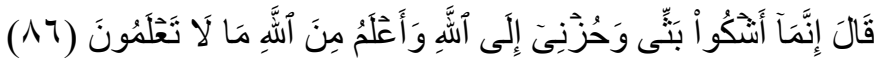

„Ja tugu i jad svoj pred Allaha iznosim, a od Allaha znam ono što vi ne znate - reče on. ${ }^{625}$

${ }^{24}$ Kur'an, Fussilet, 34.-35. 


\subsection{Kako islam podučava vjernike vještinama EI}

Ukoliko osmotrimo i istražimo proces odgoja ličnosti i usvajanja vještina, sposobnosti i znanja iz oblasti emocionalne inteligencije, uviđamo da je konačni cilj formiranje emocionalno zrele i samostalne ličnosti, spremne da na plećima ponese emanet vjere i odgoja. Kako postići taj cilj, tj. na koji način islam pristupa tom problemu?

Koncept nagrade i kazne: Islam je vjera koja je bliska ljudskoj iskonskoj naravi, i kao takva je bliska poimanju i shvatanju ljudi. Među osnovnim sredstvima koje islam koristi u odgoju ličnosti, ističe se koncept nagrade i kazne.

Pozitivno ponašanje, sposobnosti i znanja emocionalne inteligencije se $u$ islamskom učenju afirmišu uz pomoć nagrade, nakon čega se ponašanje učvršćuje i produžava. ${ }^{26}$ Vjernik nagradu za svoje postupke očekuje na drugom svijetu. Vjera u drugi svijet nosi i zahtjev za životom usklađenim $\mathrm{s}$ tom vjerom. Vjernik se obraća Allahu, dž.š. Njegovi postupci nisu motivirani nikakvim interesom. Oni dolaze iz dubine njegovog srca. Njegova nutrina i vanjština su isti. Interesuje ga samo da li će njegov Gospodar biti njime zadovoljan. On govori istinu i kada je to protiv njega, sudi i svjedoči pravedno, bez obzira koga to pogađa, čini dobro drugima i od njih ne očekuje da mu dobrim uzvrate, niti da mu izraze zahvalnost. Njegova nagrada za moralno ponašanje nije tu i neće mu na Zemlji biti isplaćena. Nagrada je tamo, na Drugom svijetu. Njegovi motivi su jaki, postojani i svjestan je da nijedno dobro djelo neće ostati nenagrađeno.

Negativni oblici ponašanja se kažnjavanjem žele dokinuti, tj. putem kazne se žele iskorijeniti loše posljedice i usvojene loše navike. Time se želi postići prekid negativnih navika, koje se također mogu ukorijeniti i učvrstiti, poput onih pozitivnih. ${ }^{27}$ Ova sredstva imaju za cilj da spriječe i potisnu negativne uticaje na odgojenika, odnosno, ako takvi uticaji već postoje, da spriječe odgojenike u vršenju loših, društveno neprihvatljivih činova i postupaka.

\footnotetext{
${ }^{25}$ Kur'an, Jusuf, 86.

${ }^{26}$ Selimović, E. (1995). Psihologija islama. Istanbul:Timas Yayinlari. Str. 92.

${ }^{27}$ Ibid., str. 94.
} 
Možemo povući paralelu između ovog islamskog koncepta, i kompletnog ustrojstva ličnosti i društva, koje također počiva na nagradi i kazni. Internalizacija, socijalizacija, socijalna i emocionalna interakcija - sve su one posljedica učvršćivanja pozitivnih i moralnih načela i ponašanja kod ljudi općenito.

\subsection{EI u islamskom pogledu na međuljudske odnose i odnos čovjeka spram drugih živih bića}

Ljudi su društvena bića, te stupaju u različite oblike socijalnih odnosa i veza. Stoga, islam kao univerzalni sistem življenja nudi praktične recepte za emocionalnu interakciju.

\subsubsection{Međuljudski odnosi}

Veličina islama se ogleda $\mathrm{i} u$ tome koliko on insistira na međusobnom potpomaganju, socijalnim programima, međusobnom opraštanju, spajanju rodbinskih veza, kakvoći bračnog odnosa, činjenju dobrih djela, uz nužnost obazrivosti i rješavanja lokalnih i globalnih problema. Islam insistira na tome da jedno društvo mora predvoditi pravda i povjerenje u svakom pogledu, što se da jasno primijetiti kad god se osvrnemo na islamske propise. Islam nam ukazuje na to da jedina razlika koju Allah dž.š., pravi među ljudima takvaluk i bogobojaznost:

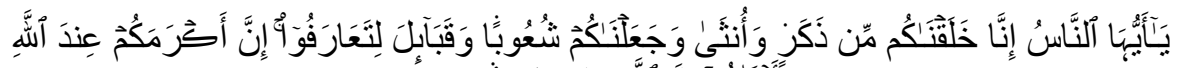

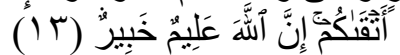

„O ljudi, Mi smo vas stvorili od jednog muškarca i od jedne žene, i na nacije i plemena smo vas podijelili kako bi se međusobno zbližavali i upoznavali; najčasniji od vas je onaj koji je prema Allahu najbogobojazniji!‘628

Osnova od koje islam kreće jeste izgradnja i odgoj svakog pojedinca kao osnove društva. Izgradnja ličnosti počinje od izgradnje odnosa između čovjeka kao roba i Uzvišenog Allaha kao njegovog Gospodara. Na tome se i zasniva islam kao sistem života, što je naravno opet suprotno onome na čemu se danas odgaja pojedinac $\mathrm{i}$ društvo. Islam se ne zaustavlja na tome. On upotpunjava i odnos

\footnotetext{
${ }^{28}$ Kur'an, El-Hudžurat, 13.
} 
čovjeka prema čovjeku, prema roditelju, rodbini, komšiji, radnom kolegi, pretpostavljenom, potčinjenom, prijatelju, muslimanu, nemuslimanu itd. - sve ovo opet biva na osnovama pokornosti zakonima koje postavio Uzvišeni Allah. Allahov Poslanik, s.a.v.s, je rekao: „,Najbolji čovjek je onaj koji najviše koristi drugim ljudima. “29 Čovjek se u islamu vrednuje i ocjenjuje po kvalitetu i količini urađenih dobrih djela. U tom smislu Allahov Poslanik, s.a.v.s, kaže: „Najbolji ljudi su oni čiji je život dug, a oni ga provode radeći dobra djela, a najgori su oni čiji je život dug, a poslovi (djela) ružni. “30

\subsubsection{Odnos između ljudi i drugih živih bića}

Osnovni islamski princip, na kojem vjernik gradi svoj odnos prema čitavoj prirodi, jeste da sve pripada Allahu, dž.š., da je On Stvoritelj svega i da je čovjek pred Njim odgovoran za svoj odnos prema prirodi. Musliman emotivno komunicira i $\mathrm{s}$ drugim bićima $\mathrm{u}$ svemiru. Dakle, od nas se očekuje da s njima postupamo $\mathrm{s}$ podjednakom brigom i poštovanjem, kao prema ljudima. Psihološka okrutnost je zabranjena u islamu na svim poljima, pa čak i prema životinjama. Poslanik, s.a.v.s., je jedne prilike ugledao čovjeka koji je svoju nogu stavio na vrat ovce i pred njenim očima oštrio nož, želeći da je zakolje, pa mu se Poslanik, s.a.v.s., obratio riječima: "Zašto to nisi učinio ranije? Zar želiš da je usmrtiš dva puta? ${ }^{\prime 31}$

Poznat je slučaj žene koja je ušla u vatru zbog mačke koju je zatvorila, nije je nahranila ni napojila, niti je pustila da sama sebi traži opskrbu, pa je umrla. Allahov Poslanik, s.a.v.s., je rekao: „Žena je ušla u Vatru zbog mačke koju je svezala - nije je hranila niti ju je pustila da se hrani sa zemlje. "32 Prema tome, nehuman odnos prema životinji može biti razlogom kazne u Džehennemu, ali isto tako lijep postupak prema životinjama može biti razlogom oprosta grijeha i ulaska u Džennet. Allahov Poslanik, s.a.v.s., je rekao: „Jedna bludnica je jednog dana vidjela psa kako kruži oko bunara. Jezik mu

${ }^{29}$ Bilježi Taberani. Preuzeto iz: Indžić, H. (2003). Osnove islamskog morala $i$ ponašanja. Travnik: Elči-Ibrahim-pašina medresa. Str. 83.

30 Biljži Tirmizi. Preuzeto iz: Indžić, H. (2003). Osnove islamskog morala $i$ ponašanja. Travnik: Elči-Ibrahim-pašina medresa. Str. 83.

31 Bilježi Hakim. Preuzeto iz: El-Gazali, M. (2003.). Karakter muslimana. Sarajevo:Bookline. Str. 377.

${ }^{32}$ Bilježi Buhari. Preuzeto iz: El-Gazali, M. (2003.). Karakter muslimana. Str. 377. 
je ispao od žeđi. Ona skinu svoju čizmu i bi joj oprošteno zbog toga. "33

\subsection{Podsticaji na usvajanje pozitivnih emocionalnih vještina i osobina u islamskom učenju}

Emocije kao što su: ljubav, nada, entuzijazam, odlučnost, itd. se snažno naglašavaju u Kur'anu i hadisima Poslanika, s.a.v.s., jer one rezultiraju pozitivnim stavom i ponašanjem muslimana unutar svojih porodica, u javnosti, te u odnosu na ostatak svijeta i sva Allahova stvorenja.

Ukoliko bismo napravili analizu međuljudskih odnosa sa stanovišta socijalne psihologije i islamskih preporuka, uvidjeli bismo mnoštvo značajnih podudarnosti. U islamu se te preporuke svode na najprihvatljivija rješenja: ćudoređe (moral), dobroćudnost, poštovanje, mirnoća, skromnost, blagost u odnosu spram drugih, čak i u nesuglasicama, umjerenost, pravednost, itd. Islam kao religija Istine, doista ne može proturječiti istini života.

Navest ćemo pojedine ajete iz Kur'ana i hadise Allahovog Poslanika, s.a.v.s., radi ilustracije navedenih teza:

Ljubav prema Allahu: Uzvišeni Allah je rekao:

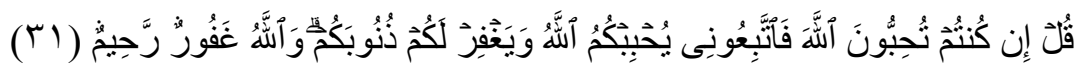

„Reci: 'Ako Allaha volite, mene slijedite, i vas će Allah voljeti i grijehe vam oprostiti! 634

Enes ibn Malik, r.a., prenosi da je Allahov Poslanik, s.a.v.s., rekao: „Ko bude imao tri osobine osjetit će slast i okus imana:

1. da mu Allah i Njegov Poslanik budu draži od svih ostalih;

2. da voli u ime Allaha i ni zbog kojeg drugog razloga;

3. da strepi od povratka u nevjerovanje nakon što ga je Allah toga spasio, kao što strepi da ga ne bace u vatru. ${ }^{\text {“35 }}$

\footnotetext{
33 Bilježi Muslim. Preuzeto iz: El-Gazali, M. (2003.). Karakter muslimana. Str. 378.

${ }^{34}$ Kur'an, Ali Imran, 13.
} 
Ulema je rekla u tumačenju ovog hadisa: „Slast imana znači uživanje $u$ ibadetima $i$ podnošenje teškoća radi Allahovog zadovoljstva i zadovoljstva Njegovog Poslanika, s.a.v.s. Sve je to važnije od ovosvjetskih prolaznih stvari. Slast imana jeste i čovjekova ljubav prema Uzvišenom Gospodaru kroz činjenje bogougodnih djela i izbjegavanje zabranjenih; zatim ljubav prema Allahovom Poslaniku, s.a.v.s."

Ljubav radi Allaha: Ebu-Hurejre, r.a., prenosi da je Allahov Poslanik, s.a.v.s., rekao: „Tako mi onoga u čijoj je ruci moja duša, nećete ući u Džennet dok ne budete vjerovali; a nećete vjerovati dok jedni druge ne zavolite. Hoćete li da vas uputim kako ćete postići ljubav među vama? Širite selam!“36 Imam Ahmed ibn Hanbel upitan je o tome šta je to ljubav radi Allaha, pa je rekao: „To je ljubav prema čovjeku bez ovosvjetskih interesa."

Nada: Nada predstavlja jednu od krucijalnih osobina razvijene emocionalne inteligencije. Ona je vjerovanje da postoji način i volja za ostvarivanje ciljeva pojedinca, ma kakvi oni bili. Islam u okviru svog učenja ističe značaj nade. Uzvišeni Allah nas u časnoj Knjizi bodri da ne gubimo nadu u Njegovu milost. Uzvišeni kaže:

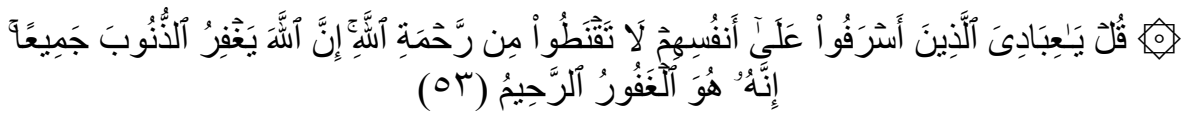

"Reci: O robovi Moji koji ste se prema sebi ogriješili, ne gubite nadu u Allahovu milost, Allah će oprostiti sve grijehe, On puno prašta i milostiv je." 37

Nužno je nakon pokajanja ostaviti grijehe i činiti dobra djela, jer ispravna nada mora biti popraćena činjenjem dobrih djela, kako kaže Milostivi:

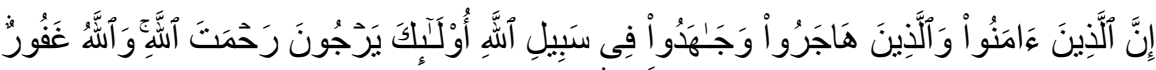

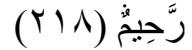

"Oni koji vjeruju i koji hidžru učine i bore se na Allahovom putu, oni se Allahovoj milosti nadaju." ${ }^{38}$

${ }^{35}$ Ez-Zubejdi, A. (2004.). Buharijina zbirka-sažetak. Sarajevo:El-Kalem. Str. 19.20.

${ }^{36}$ El-Munziri, Z. (2004.). Muslimova zbirka-sažetak. Sarajevo:El-Kalem. Str. 29.

${ }^{37}$ Kur'an, Ez-Zumer, 53. 
Blagost $\boldsymbol{i}$ skromnost: Imran b. Himar, r.a., prenosi da je Vjerovjesnik, s.a.v.s., rekao: „Uistinu, Allah mi je objavio da budete blagi, skromni jedni prema drugima i da se ne uzdižete jedan nad drugim i da ne činite nasilje jedan drugom. ${ }^{39}$ Ako pogledamo život Allahova Poslanika, s.a.v.s, vidjet ćemo da je, uglavnom, njegov život bio protkan blagošću i nježnošću, zbog čega bi i govorio: „Blagost se neće naći ni pri jednoj stvari, a da je neće uljepšati... “40

\subsection{Pogled islama na negativne emocionalne reakcije}

Savremene civilizacije i države različitim metodama i vrstama nadzora nastoje kontrolirati ponašanje i djelovanje ljudi, ali i pored velikih napora slabo uspijevaju suzbiti kriminal, nasilje, korupciju, nemoral i ostale probleme društva.

Islam rješavanju ovih problema pristupa na jedan poseban način. Iako islam za određene prijestupe propisuje rigorozne kazne na ovom svijetu, mnogo više pažnje pridaje usađivanju jake svijesti kod ljudi da su pod stalnom Allahovom kontrolom i praćenjem, da Mu ništa ne mogu sakriti i da će za sve odgovarati. Islam ističe pogubnost negativnih emocija na sveopće stanje čovjeka, poput: bijesa, depresije, mržnje, zavisti, itd. Musliman se savjetuje da prakticira strogu kontrolu nad tim destruktivnim emocijama, te da se pokaje ukoliko su one uticale na djela ili stavove prema drugima.

Islamski učenjaci kažu da je najbolja opomena i kontrola ljudskih djela svijest o konstantnom Božijem nadzoru. Zbog toga, veći dio Kur'ana govori o moralu i toj svijesti, a manji dio govori o pravnim propisima, jer je kur'ansko stanovište da je za pravilan razvoj društva važnije učvrstiti vjeru i moral kod ljudi, nego donositi pravne odredbe, koje, bez jake vjere i morala, ne bi imale velike vrijednosti i efekta.

Uzvišeni Allah na mnogim mjestima u Kur'anu naglašava čovjeku da je pod stalnim nadzorom, pa kaže:

${ }^{38}$ Kur'an, El-Bekare, 218.

39 Bilježi Muslim. Preuzeto iz: Hakki, A. M.(2004.). Moral muslimana. Sarajevo:Bookline. Str. 122.

40 Bilježi Muslim. Preuzeto iz: Hakki, A. M.(2004.). Moral muslimana. Sarajevo:Bookline. Str. 110. 


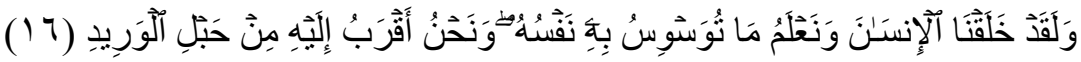

"Mi smo čovjeka stvorili i znamo šta mu sve njegova duša došaptava, i Mi smo mu bliži od žile kucavice. “41

Svaki čovjek koji je svjestan ovih ajeta, bojat će se Allaha i neće se olahko odlučiti na grijeh, a kamoli biti ustrajan u njemu. Allahov Poslanik, s.a.v.s, u hadisu u kojem ga je Džibril upitao šta je to ihsan (vrhunac vjere), odgovorio je: „Da obožavaš Allaha kao da Ga vidiš, jer ako ti Njega ne vidiš, On tebe vidi."

\section{ZAKLJUČAK}

Putem obrade teme rada došlo se do slijedećih zaključaka:

- Vanjski svijet opažamo, saznajemo o njemu, ali ga i doživljavamo na subjektivni, lični način, putem emocija čiju pojavu prate unutrašnje i spoljašnje tjelesne promjene. Emocije se, stoga, mogu definisati kao doživljaj našeg vrednovanja i subjektivnog odnosa prema stvarima, ljudima, događajima i prema sopstvenim postupcima.

- Riječ inteligencija potiče od latinske riječi inteligere i znači razumijeti, shvatiti. Psiholozi koriste inteligenciju kao crtu ličnosti koja može barem djelomično protumačiti način na koji ljudi reaguju ili se ponašaju u različitim situacijama.

- Emocionalna inteligencija (EI) ima korijene u konceptu "socijalne inteligencije", koju je po prvi put identifikovao E.L. Torndike, 1920. godine. Utemeljenje za pojavu koncepta emocionalne inteligencije pronalazimo u Gardnerovoj (1983.) teoriji višestrukih inteligencija; i Sternbergovoj (1985.) triarhičkoj (trosložnoj) teoriji inteligencije. Svoju popularnost, koncept emocionalne inteligencije bilježi pojavom knjige psihologa Danijela Golemana. Ukratko definirana, emocionalna inteligencija je sposobnost da se opaze emocije, da im se priđe i da se izazovu, kako bi pomogle procesu mišljenja.

- Emocije u okviru islamskog učenja imaju svoje vrijednosno značenje kao fundamentalni elementi ljudske duše. Islam podučava

\footnotetext{
${ }^{41}$ Kur'an, Kaf, 16.

${ }^{42}$ Ez-Zubejdi, A. (2004), Buharijina zbirka-sažetak. Sarajevo:El-Kalem. Str. 33.
} 
umjerenosti u svim sferama života, nastojeći da kreira harmoniju, tako da pojedinac bude $\mathrm{u}$ konstantnom miru sa samim sobom, univerzumom, i Allahom.

- Pet temeljnih dimenzija emocionalne inteligencije se navode $\mathrm{u}$ Kur'anu, kao izvoru Upute. To su: upoznavanje vlastitih emocija, upravljanje emocijama, samomotivacija, prepoznavanje emocija $u$ drugima, snalaženje u društvenim vezama. Islam u svojim temeljnim izvorima podstiče na njihovo usvajanje.

- Islam je vjera koja je bliska ljudskoj iskonskoj naravi, i kao takva je bliska poimanju i shvatanju ljudi. Među osnovnim sredstvima koje islam koristi u odgoju ličnosti, ističe se koncept nagrade i kazne. Pozitivno ponašanje, sposobnosti i znanja emocionalne inteligencije se $\mathrm{u}$ islamskom učenju afirmišu uz pomoć nagrade, nakon čega se ponašanje učvršćuje i produžava. Negativni oblici ponašanja se kažnjavanjem žele dokinuti, tj. putem kazne se žele iskorijeniti loše posljedice, usvojene loše navike.

- Osnova od koje islam kreće jeste izgradnja i odgoj svakog pojedinca kao osnove društva. Izgradnja ličnosti počinje od izgradnje odnosa između čovjeka kao roba i Uzvišenog Allah kao njegovog Gospodara. On upotpunjava i odnos čovjeka prema čovjeku, prema roditelju, rodbini, komšiji, radnom kolegi, pretpostavljenom, potčinjenom, prijatelju, muslimanu, nemuslimanu.

- Emocije kao ljubav, nadu, entuzijazam, odlučnost, itd. se snažno naglašavaju u Kur'anu i hadisima Poslanika, s.a.v.s. Islam ističe pogubnost negativnih emocija na sveopće stanje čovjeka, poput: bijesa, depresije, mržnje, zavisti, itd. Musliman se savjetuje da prakticira strogu kontrolu nad tim destruktivnim emocijama, te da se pokaje ukoliko su one uticale na djela ili stavove prema drugima.

- Islamski učenjaci kažu da je najbolja opomena i kontrola ljudska svijest o tome da Allah prati insana i da sve zna o njemu. Zbog toga veći dio Kur'ana govori o moralu i toj svijesti, a manji dio govori o pravnim propisima, jer je kur'ansko stanovište da je za pravilan razvoj društva važnije učvrstiti vjeru i moral kod ljudi nego donositi pravne odredbe, koje, bez jake vjere i morala, ne bi imale velike vrijednosti i efekta. 


\section{Literatura:}

\section{Kur'an i prevodi Kur'ana:}

1. El-Kur'anu-l-kerim, Mushafu-l-Medinetin-Nebevijjeh (Kur'an Casni, medinska verzija Mushafa), Mudžemme'u-l-melik Fahd, 1405.h.g.

2. Korkut B., Kur'an s prevodom, Štamparija kralja Fahda, Saudijska Arabija, Medina, 1412.h.

\section{Knjige:}

3. Ebu Gudde, A. (2003). Poslanik kao učitelj i njegovi metodi u podučavanju. Novi Pazar: El-Kelimeh.

4. El-Buhari, M. ibn I. (2009). Knjiga o edebu. Mostar: IKC Mostar.

5. El-Gazali, M. (2003). Karakter muslimana. Sarajevo: Bookline.

6. El-Munziri, Z. (2004). Muslimova zbirka hadisa-sažetak. Sarajevo: El-Kalem.

7. Ez-Zubejdi, A. (2004). Buharijina zbirka hadisa-sažetak. Sarajevo: El-Kalem.

8. Goleman, D. (2004). Emocionalna inteligencija. Zagreb: Mozaik knjiga.

9. Goleman, D. (2008). Socijalna inteligencija. Beograd: Geopoetika.

10. Hakki, A. M. (2004). Moral muslimana. Sarajevo: Bookline.

11. Indžić, H. (2003). Osnove islamskog morala i ponašanja. Travnik: Elči Ibrahimpašina medresa.

12. Indžić, S. (2004). Savremeni prikaz Poslanikove ličnosti. Travnik: Elči Ibrahimpašina medresa.

13. Mubejjid, M. (2008). Nauči vladati svojim emocijama - emocionalna inteligencija; naučni i islamski pogled, Sarajevo: Dobra knjiga.

14. Rathus, S.A. (2000). Temelji psihologije. Jastrebarsko: Naklada Slap.

15. Selimović, E. (1995). Psihologija islama. Istanbul: Timas Yayinlari.

\section{Članci na engleskom jeziku:}

16. Peter Salovey and John D. Mayer, Emotional intelligence, Baywood Publishing, 1990.

\section{Internet stranice:}

17. gencelowich.blogspot.com

18. www.centar-zdravlja.net

19. www.emocionalnainteligencija.com

20. www.virovitica.info

21. www.wikipedia.com 
Osman Ramic, Ph D and Nedim Botic, Bachelor of Islamic religious education

\section{BASICS OF ISLAMIC VIEW ON THE CONCEPT OF THE EMOTIONAL INTELLIGENCE}

\section{SUMMARY}

With the analysis of the topic Basics of Islamic view on the concept of Emotional Intelligence, we tried to give a conceptual definition of the Emotional Intelligence as a relatively new scientific concept and its relationship with the Islamic teachings. We attempted to identify and analyze the concept of Emotional Intelligence in the light of Islamic teaching and its place in the sources of Islam. Islam as a universal concept of life offers the solutions to all issues and problems of mankind until the Day of Judgement, and contains integrated elements of Emotional Intelligence.

Emotional Intelligence as an essential component of a successful life and functioning includes: emotional sensitivity, interpersonal and intrapersonal skills, social sensitivity, communication skills, high levels of tolerance, high levels of adaptability, sociability, cooperation, and daily in collaboration in various everyday life situations and circumstances.

Harmonious interpersonal relationships in all the structures are the basic prerequisites for successful work and life, and require a high Emotional Intelligence. So rightfully D. Goleman gives EI an advantage over academic intelligence.

Developed Emotional Intelligence is a must for educators, health professionals, managers, politicians, educators, psychologists, social workers, therapists, lawyers, judges, policemen and others.

A need for deeper and more comprehensive research and study of the role and importance of Emotional Intelligence in modern life and work remains even today.

Keywords: Islam, emotions, Emotional Intelligence, intrapersonal and interpersonal sensitivity, empathy 
الأستاذ الدكتور عثمان راميتش ونديم بوتيتش - بكالوريوس التربية الإسلامية

\section{أسس الرؤية الإسلامية لمفهوم الذكاء العاطفي}

\section{خلاصة البحث}

من خلال تناول موضوع أسس الرؤية الإسلامية لمفهوم الذكاء العاطفي حاولنا

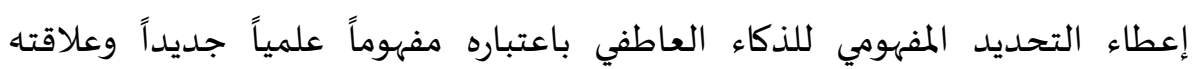

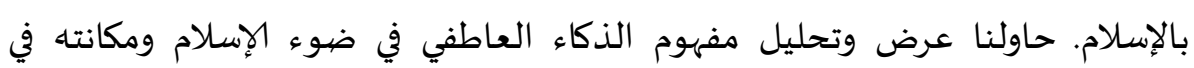

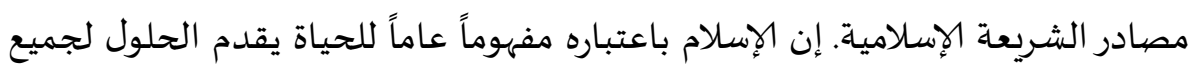

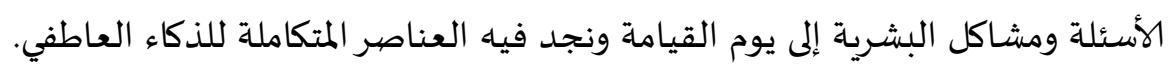

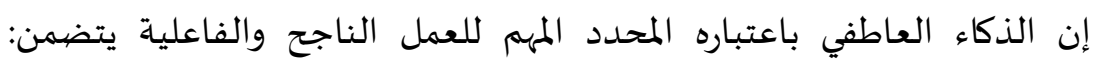

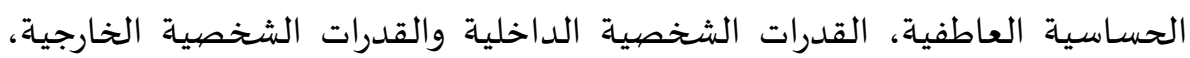

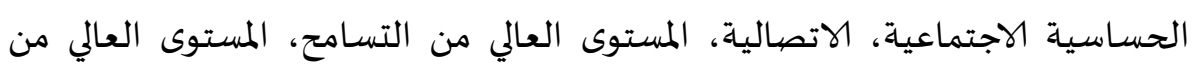

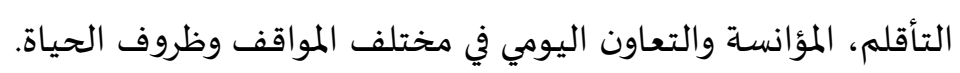

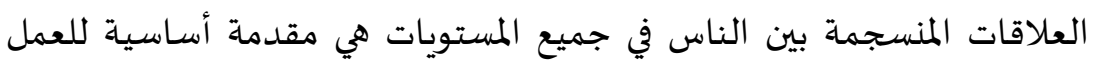

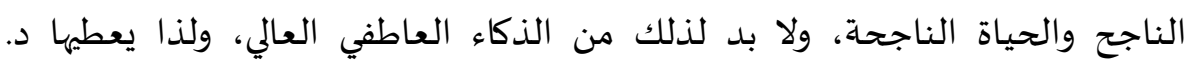
غوليمان وبحق الأولوية مقارنة بالذكاء الأكاديمي.

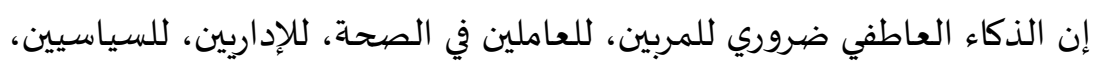

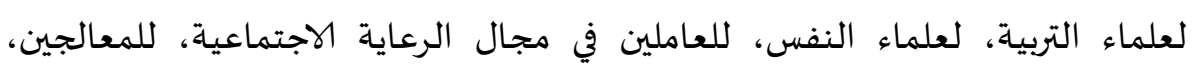

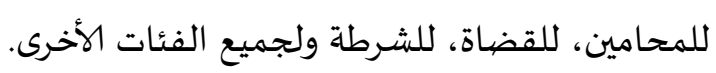

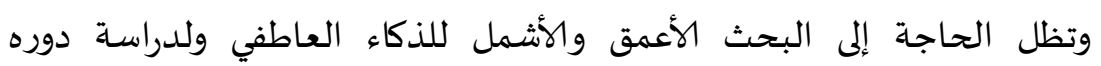

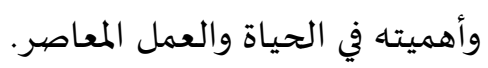

الكلمات الرئيسة: الإسلام، العواطف، الذعاصن، الذكاء العاطفي، الحساسية الداخلية و

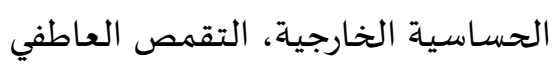

